\title{
Sequence Organization of Requests among Australian English and Saudi Arabic Speakers: A Contrastive Study
}

\author{
Saad Al-Gahtani \\ Kind Saud University \\ algsaad@ksu.edu.sa
}

\begin{abstract}
Previous research on cross-cultural pragmatics has primarily focused on how native speakers of different languages perform speech acts in relation to politeness and directness. However, Gabriele Kasper (2006), among others, has called for adopting a more discursive approach rather than analyzing data according to the Cross-Cultural Speech Act Realization Project (CCSARP) coding scheme. Therefore, this paper used Conversation Analysis for Interlanguage Pragmatics to investigate sequence organization of requests in Australian English and Saudi Arabic using role-play scenarios. It specifically examined pre-expansions, pre-pres, accounts in request turn, insertexpansions, and post-expansions, and the extent to which the social variable power affects them. The results showed that both languages shared some regularities in aspects of sequence organization but differed in others. Power influenced the production of some regularities in both languages.
\end{abstract}

\section{Keywords}

interlanguage pragmatics, conversation analysis, sequence organization

* The author would like to extend their sincere appreciation to the Deanship of Scientific Research at King Saud University for funding this Research Group No (RG-1435-038). 


\section{Résumé}

Les recherches antérieures sur la pragmatique interculturelle se sont principalement concentrées sur la manière dont les locuteurs natifs de différentes langues accomplissent des actes de parole en lien avec la politesse et la franchise. Cependant, Gabriele Kasper (2006), entre autres, a appelé à adopter une approche plus discursive plutôt qu'à analyser les données selon le système de codification du Cross-Cultural Speech Act Realization Project (CcSARP). Par conséquent, cet article utilise l'Analyse Conversationnelle pour la Pragmatique Interlangue afin d'explorer l'organisation séquentielle de requêtes en anglais australien et en arabe saoudien, en utilisant des scénarios de jeu de rôle. L'article examine spécifiquement les pré-expansions, les préprés, les justifications dans les tours de requête, les expansions insérées et les postexpansions, ainsi que l'étendue dans laquelle le pouvoir de la variable sociale les affecte. Les résultats montrent que les deux langues partagent certaines régularités dans des aspects de l'organisation séquentielle, mais diffèrent dans d'autres. Le pouvoir a influencé la production de certaines régularités dans les deux langues.

\section{Mots clefs}

Pragmatique interlangue, analyse conversationnelle, organisation séquentielle

\section{Introduction}

It is believed speech acts are governed by universal pragmatic principles. ${ }^{1}$ Penelope Brown and Steven Levinson suggest there is a relationship between politeness and directness - the more indirect the speech act, the more polite. ${ }^{2}$ A relatively large number of studies exist comparing the production of speech acts in different languages. Contrastive studies have looked at requests, ${ }^{3}$

1 John Langshaw Austin, How to Do Things with Words, Oxford, Oxford University Press, 1962; John R. Searle, Expression and Meaning: Studies in the Theory of Speech Acts, Cambridge, Cambridge University Press, 1979.

2 Penelope Brown and Steven Levinson, Politeness: Some Universals in Language Usage, Cambridge, Cambridge University Press ("Studies in interactional sociolinguistics", 4), 1987.

3 Rob Le Pair, "Spanish request strategies: a cross-cultural analysis from an intercultural perspective," Language Sciences, 18/3-4 (1996), p. 651-670; Carol Rinnert and Hiroe Kobayashi, "Requestive hints in Japanese and English," Journal of Pragmatics, 31/9 (1999), p. 1173-1201. 
compliment responses, ${ }^{4}$ apologies, ${ }^{5}$ refusals, ${ }^{6}$ and invitations. ${ }^{7}$ However, these studies yielded contradictory results. Some supported the concept of universal pragmatic principles and a relationship between directness and politeness, while others called it into question. What the studies have in common is studying speech acts as segmented forms rather than examining how they are sequentially organized. As a result, some researchers have called for a more holistic approach when examining Interlanguage Pragmatics which can be done by using Conversation Analysis. ${ }^{8}$

The literature, however, shows that Conversation Analysis uses emic analytical methods on naturally occurring data, in contrast to Interlanguage Pragmatics that uses etic analytical methods on elicited data, as well as examining the effect of participant identities and social variables. ${ }^{9}$ This asymmetry has led to the emergence of Conversation Analysis-for-Interlanguage Pragmatics, ${ }^{10}$ which aims to apply emic analytical perspectives to data, either natural or elicited, as well as investigate the effect of any variables of interest. ${ }^{11}$

$4 \quad$ Chen-Hsin Tang and Grace Qiao Zhang, "A contrastive study of compliment responses among Australian English and Mandarin Chinese speakers," Journal of Pragmatics, 41/2 (2009), p. 325-345.

5 Luanga A. Kasanga and Joy-Christine Lawanga-Lumu, "Cross-cultural linguistic realization of politeness: A study of apologies in English and Setswana," Journal of Politeness Research, 3/1 (2007), p. 65-92; Malgorzata Suszczynska, "Apologizing in English, Polish and Hungarian: Different languages, different strategies," Journal of Pragmatics, 31/8 (1999), p. 1053-1065.

6 Jihyun Kwon, "Expressing refusals in Korean and in American English," Multilingua, 23/4 (2004), p. 339-364; Gayle Nelson, Mahmoud Al Batal and Waguida El Bakary, "Directness vs. indirectness: Egyptian Arabic and U.S. English communication style," International Journal of Intercultural Relations, 26/1 (2002), p. 39-57.

7 Zohreh Rasekh Eslami, "Invitations in Persian and English: Ostensible or genuine?," Intercultural Pragmatics, $2 / 4$ (2005), p. 453-480.

8 E.g. Gabriele Kasper, "Speech acts in interaction: Towards discursive pragmatics," in Pragmatics and Language Learning, eds. Kathleen Bardovi-Harlig, J. César Félix-Brasdefer and Alwiya S. Omar, Honolulu, University of Hawaii at Manoa-National Foreign Language Resource Centre ("Pragmatics and Language Learning Monograph Series”, 11), 2006, p. 281-314.

9 Saad Al-Gahtani and Carsten Roever, "Proficiency and sequential organization of L2 requests," Applied Linguistics, 33/1 (2012), p. 42-65.

10 Paul Seedhouse, "Conversation analysis and language learning," Language Teaching, 38/4 (2005), p. 165-187; Paul Ten Have, Doing Conversation Analysis, London-Thousand OaksNew Delhi, Sage ("Introducing qualitative methods"), 2007.

11 John Heritage and Steven Clayman, Talk in Action, Chichester-Malden, Wiley-Blackwell (“Language in society", 38), 2010. 
The speech act of request is considered the most researched speech act in the field. ${ }^{12}$ Over the past decade, a number of empirical studies have also been carried out to investigate requests from a Conversation Analysis perspective. For example, Emanuel Schegloff's analysis of sequence organization in English, ${ }^{13}$ Cameron Taleghani-Nikazm's investigation of request sequences in German, ${ }^{14}$ Saad Al-Gahtani and Carsten Roever's study on sequential organization of English L2 requests, ${ }^{15}$ Gabriele Kasper and Steve Ross's examination of multiple requests in English, ${ }^{16}$ Roever and Al-Gahtani's analysis of multiple requests in Arabic as a second language, ${ }^{17}$ and Trine Heinemann's study on entitlement in Danish interrogative requests. ${ }^{18}$ However, a comparison of sequence organization of requests across languages has not yet been researched. Given that previous Interlanguage Pragmatics studies have reported differences of request production across languages and cultures, further research is needed to establish the extent to which sequence organization of requests varies across languages.

This paper contributes to the existing literature of Conversation Analysis and Interlanguage Pragmatics using Conversation Analysis to investigate differences between the sequential structure of requests in Australian English and Saudi Arabic using role-play scenarios. Specifically, it focuses on the production of pre-request sequences, insert expansion, post-expansion, and accounts within request sequences, as well as the influence of power on sequence organization.

Conversation Analysis is used for analyzing interactive data with a strong emphasis placed on how the interaction is co-constructed and organized by

12 Gabriele Kasper, "Data collection in pragmatics research," in Culturally Speaking: Culture, Communication and Politeness Theory, ed. Helen Spencer-Oatey, London-New York, Continuum, 2008, p. 279-303.

13 Emanuel A. Schegloff, Sequence Organization in Interaction, Cambridge, Cambridge University Press, 2007.

14 Cameron Taleghani-Nikazm, Request Sequences: the Intersection of Grammar, Interaction and Social Context, Amsterdam-Philadelphia, Benjamins ("Studies in discourse and grammar", 19), 2006.

15 Al-Gahtani and Roever, "Proficiency and sequential organization of L2 requests."

16 Gabriele Kasper and Steve Ross, "Multiple questions in oral proficiency interviews," Journal of Pragmatics, 39/11 (2007), p. 2045-2070.

17 Carsten Roever and Saad Al-Gahtani, "Multiple requests in Arabic as a second language," Multilingua, 34/3 (2015), p. 405-432.

18 Trine Heinemann, “Will you or can't you?: Displaying entitlement in interrogative requests," Journal of Pragmatics, 38/7 (2006), p. 1081-1104. 
both parties. ${ }^{19}$ Analyzing adjacency pairs is considered one of the main methods Conversation Analysis uses to illustrate how social activities (i.e. speech acts) are organized in talk-in-interaction. ${ }^{20}$ Ian Hutchby and Robin Wooffitt defined adjacency pairs as "pairs of utterances which are ordered, that is, there is a recognizable difference between first parts and second parts of the pair; and in which given first pair parts require particular second parts." ${ }^{21}$ In the speech act of requesting, for example, the adjacency pair consists of a first pair part (i.e. request) and a second pair part (i.e. acceptance or rejection) and they most likely appear next to each other.

It is evident that Conversation Analysis in general and the study of adjacency pairs specifically, focus mainly on how sequences of talk are organized in interaction. Schegloff points out that sequence organization refers to "the organization of courses of action enacted through turns-at-talk - coherent, orderly, meaningful successions or "sequences" of actions or "moves." ${ }^{22}$ In his examination of sequence organization in English, Schegloff examined various concepts pertinent to sequence organization, namely, pre-expansion, preliminaries to preliminaries, insert-expansion and post-expansion. ${ }^{23}$

According to Schegloff, a pre-expansion is a sequence (i.e. an adjacency pair) which is placed before the base adjacency pair (e.g. request-sequence) and has two main functions in talk-in-interaction: 1) to project the dispreferred action (i.e. request) such as accounts/explanations, and 2) to oblige the other party to issue a second pair part, most likely leading to the production of the request. ${ }^{24}$ However, a pre-expansion itself can also be preceded by yet another sequence that serves to build up to the request. This sequence is called a preliminary to preliminaries (pre-pres). ${ }^{25}$ An example of pre-pres is "can you do me a favor?"

Insert-expansions are sequences placed between the base first pair part (i.e. request) and the base second pair part (i.e. acceptance or rejection) and can be divided into two types: post-first insert expansion and pre-second insert expansion. ${ }^{26}$ The former relates to a hearing problem or a misunderstanding of

\footnotetext{
19 Al-Gahtani and Roever, "Proficiency and sequential organization of L2 requests"; Ian Hutchby and Robin Wooffitt, Conversation Analysis: Principles, Practices, and Applications, Cambridge-Malden, Polity Press, 1998.

20 Schegloff, Sequence Organization in Interaction.

21 Hutchby and Wooffitt, Conversation Analysis, p. 39.

22 Schegloff, Sequence Organization in Interaction, p. 2.

23 Ibid.

24 Ibid.

25 Ibid.

26 Ibid.
} 
the request, whereas the latter relates to seeking further information needed to decide whether to produce a request acceptance or rejection. ${ }^{27}$

Post-expansions are sequences occurring after the production of the request response. Schegloff identified two types of post-expansions: minimal and non-minimal. ${ }^{28}$ Minimal post-expansion refers to a turn produced in relation to the request response that doesn't entail a second pair part, serving as a "sequence-closing third," such as "okay" or "that's great."29 On the other hand, non-minimal post-expansion refers to adjacency pairs produced after the request response, which are relevant to prior talk and require a second pair part.

Some of the aforementioned aspects of sequence organization have been investigated in languages other than English. For instance, Taleghani-Nikazm examined telephone conversations and face-to-face interactions between relatives and close friends in German. ${ }^{30}$ She found German speakers, like English speakers, used pre-pres and pre-expansions before requests, however, she also found that accounts sometimes occurred after the production of the request, showing that the placement of accounts varies across languages. Accounts tend to appear before requests in English. ${ }^{31}$

Although Taleghani-Nikazm examined only pre-request and request sequences in German, her study shows some variations of sequence organization between English and German. ${ }^{32}$ This raises questions about the universality of sequence organization. The present study explores this further by investigating sequence organization in Australian English and Saudi Arabic. Of interest is whether native speakers approach sequence organization similarly or differently. In addition, this study examines whether power affects sequence organization of requests in both languages.

\section{The Data}

Thirty-one male subjects participated in this study. The sample was divided into two groups: Saudi Arabic native speakers (18) and Australian English native speakers (13). Saudi Arabic native speakers were enrolled in different

\footnotetext{
27 Emanuel Schegloff, Gail Jefferson and Harvey Sacks, "The preference for self-correction in the organization of repair in conversation," Language, 53/2 (1977), p. 361-382.

28 Schegloff, Sequence Organization in Interaction.

29 Ibid., p. 118.

3o Taleghani-Nikazm, Request Sequences.

31 Schegloff, Sequence Organization in Interaction.

32 Taleghani-Nikazm, Request Sequences.
} 
university programs and language schools in Australia. Australian English native speakers were university students in various programs in Melbourne, Australia. Participants' ages ranged from 19 to 42 .

The data was collected by means of open role plays. They included three request situations, which solely varied the influence of one context variable (power). All situations were low imposition and low social distance. Each situation contained a complicating factor, which was not mentioned on the participant's role play card. In the situation 1, the participant asks his housemate to go to the supermarket and buy some bread (= power) but the housemate is watching $\mathrm{TV}$ and cannot go right away. In the situation 2, a student asks his professor to give him the lecture notes from the last lecture (+ power), which he did not attend due to illness. Before giving him the lecture notes, the professor asks him why he did not attend and whether he is feeling better. In the situation 3, the participant is a tutor who asks his student to inform his class that there is no seminar that day (- power). The student confirms the information before accepting the request.

The role play cards were administered to the participants one at a time. For each situation, they were given five minutes to read the scenario carefully in order to absorb the role they would subsequently play. Before the role play commenced, the researcher asked the participant if the role play scenario was clear, or if they had any further questions they wished to ask. In an attempt to ensure the clarity of the scenario, the researcher also explained the scenario to the participant in his own words. All role plays were audio taped. In all English and Arabic role plays, the researcher played the role of conductor in order to eliminate potential variables. The role play conductor tried his best to treat all participants equally.

\section{Results}

\section{Pre-Expansion}

The production of pre-expansions was evident in both groups and no noticeable differences were observed. Both groups tended to produce multiple preexpansions in a request sequence, as exemplified in the following two excerpts.

Excerpt 1: Australian English native speaker: pre-expansion
(1) D: Hi (first name).
(2) I: $\mathrm{Hi}$
(3) D: How you're doin?
(4) I: Good, thank you and yourself? 
(5) D: => I'm pretty good. Uhm I've been a bit flat out

(6) I: .hhh

(7) $\mathrm{D}:=>$ I'm really busy at uni

(8) I: Yeah

(9) D: => I've got so much on at the moment and I've got all these assignments to do... and... I haven't had a time to do any shopping or anything [

(10) I: $[. \mathrm{hh}$

(11) $\mathrm{D}:=>$ And there is nothing to eat... and I really need to get some bread and some other things [

(12) I: [Yeah

(13) D: And I was wondering... if you got any time if you could go down to the shops because I just can't spare any time I'm really busy?

(14) I: Yeah, it's all right but at the moment I'm watching this match and it's gonna finish in... half an hour, so is it all right or do you want me to go now?

Excerpt 2: Saudi Arabic native speaker: pre-expansion

(1) H: Al-salāmu 'alaykum.

Peace upon you.

Peace be upon you (hello).

(2) I: Wa-'alaykum al-salām.

And upon you peace.

Peace be upon you, too (hello).

(3) H: Lā mu'āhada yā duktūr (first name) mumkin āhuud min waqtik ğuz' basit?

Sorry oh professor (first name) possible take from your time a bit little?

Sorry professor (first name) is it possible to take a little bit from your time?

(4) I: Tafaḍdal.

Sure.

Sure.

(5) $\mathrm{H}:=>$ Al-usbū'al-mādī kunt Allah yahfazik marìd]

Week last was God protect you sick [

Last week I was sick, may God protect you [

(6) I: [īh.

[yeah.

[Yeah.

(7) $\mathrm{H}:=>$ Wa-kunt fī wa ka wa-mā astața't annī aḥ̣ur [

And was in ailment and no I could I attend [

And I was sick and I couldn't attend [ 
(8) I: [İh.

[Yeah.

[Yeah.

(9) $\mathrm{H}: \Rightarrow>$ Wa-bi-l-tālì mā astata't an āhud al-mulahhasāt.

And therefore no I could to take the lecture notes.

And I couldn't therefore take the lecture notes.

(10) I: Īh wšlūn ḥālatuk alān?

Yeah how your condition now?

Yeah, how do you feel now?

(11) H:Al-ḥamd li-Llāh ubšširuk wa-šukran li-su'ālik.

Thanks God good and thanks for asking.

Thanks God, good and thanks for asking.

(12) I: Allahyahfazik.

God protect you.

May God protect you.

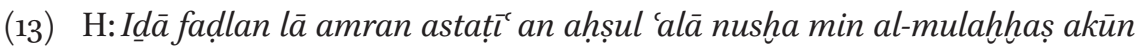
laka šākiran.

If favour not command I can to get with copy from the lecture notes be for you grateful.

If I could please have a copy of the lecture notes, I'll be grateful.

(14) I: 'Indī iddat nusah fa-hadì al-nusha lak.

I have several copies so this copy for you.

I have several copies so you may have this copy.

Excerpt 1 shows the Australian English native speaker (David) issuing a preexpansion in line 5 "I've been a bit flat out" after the occurrence of opening and greeting exchanges, lines 1-5. However, he launches another pre-expansion in line 7 "I'm really busy at uni" and the interlocutor produces a go-ahead response, line 8. The Australian English native speaker continues to issue more pre-expansions in line 9: "I've got so much on at the moment and I've got all these assignments to do... and... I haven't had a time to do any shopping or anything" and in line 11 "and there is nothing to eat... and I really need to get some bread and some other things." Following further go-ahead responses by the interlocutor, lines 10 and 12, the Australian English native speaker finally launches the base first pair part, i.e. his request, in line 13 "and I was wondering... if you got any time if you could go down to the shops." Similarly, excerpt 2 shows that the Saudi Arabic native speaker (Hassan) produces multiple preexpansions before the production of the base first pair part. He issues three pre-expansions in lines 5 (al-usbü cal-māḍ̄ kunt Allah yahfazik marị̀: "last week I was sick, may God protect you"), 7 (wa-kunt fìwaka wa-mā astața't annī 
ahdur: "and I was sick and I couldn't attend") and 9 (wa-bi-l-tāli mā astața't an āhud al-mulahhașāt: "And I couldn't therefore take the lecture notes"). Following interlocutor's go-ahead responses, the Saudi Arabic native speaker launches his request in line 13 (ídā faḍlan lā amran astațí' an ahșul 'alā nusha min al-mulahhas akūn laka šäkiran: "if I could please have a copy of the lecture notes, I'll be grateful").

These examples show not only use of pre-expansion in both Australian English and Saudi Arabic but rather use of multiple pre-expansions. Interestingly, although the interlocutor never rejects or even questions participants' requests, most participants in both groups showed a heavy reliance on the production of multiple pre-expansions. This may be because requests are considered "dis-preferred" actions and "face-threatening" acts, ${ }^{33}$ compelling the speaker to employ more interactional moves to mitigate the request. When examining the influence of power on the occurrence of pre-expansions, the results indicate that both groups invariably used pre-expansions with the housemate (Saudi Arabic: 35 occasions; Australian English: 26 occasions), professor (Saudi Arabic: 33 occasions; Australian English: 25 occasions) and student (Saudi Arabic: 33 occasions; Australian English: 23 occasions).

\section{Preliminaries to Preliminaries}

The two groups differed in their use of pre-pres. Australian English native speakers rarely produced pre-pres (5 out of 39 interactions) whilst Saudi Arabic native speakers frequently issued pre-pres in the corpus ( 31 out of 54 interactions). Excerpt 3 exemplifies the infrequent occurrence of pre-pres in the Australian English native speaker data whereas excerpt 4 exemplifies the frequent occurrence of pre-pres in the Saudi Arabic native speaker data.

Excerpt 3: Australian English native speaker: no pre-pre

(1) N: Excuse me, teacher.

(2) I: Yes.

(3) N: Sorry to bother you [

(4) I: [No, it's all right.

(5) N: Good, uhm... unfortunately I was sick last week [

(6) I: [.hh.

(7) N: And I didn't have a chance to come to the lecture [

(8) I: [I see. Hopefully you're feeling better now?

(9) N: Yep, thank you. I'm feeling much better. I'm wondering if I could get a copy of the lecture notes [ 
(10) I: [Yeah sure.

(11) N: For last week?

(12) I: Yeah. I have extra copies... and this one is for you.

Excerpt 4: Saudi Arabic native speaker: pre-pres
(1) A: Law samaht (first name).
Excuse me (first name).
Excuse me (first name).
(2) I: Halā ustā $\underline{d}$ (first name).
Hi teacher (first name).
Hi teacher (first name).
(3) A: Salām 'alaykum wšlūnak (first name)?
Peace upon you how you (first name)?
Peace be upon you, how are you (first name)?

(4) I: Allahysallimuk.

God grant you health.

May God grant you health.

(5) A: Wšlūn al-imtihānāt ma'ak?

How the exams with you?

How are the exams going?

(6) I: Al-hamd li-Llah.

Thanks God.

Thanks God.

(7) A: Wšlūn al-dirāsa?

How the study?

How is the study?

(8) I: Tamām.

Good.

Good.

(9) A: Umūrukum zayna?

Your matters all right?

Is everything all right?

(10) I: Al-hamdu li-Llah.

Thanks God.

Thanks God.

(11) A: => Mumkin mink hidma?

Possible from you favour?

Is it possible to do me a favour?

(12) I: Tafaddal.

Sure.

Sure. 
(13) A: Abīk tuballig̉ zumalāik annī l-yawm mā aqdar aḥưr.

I want you tell your classmates I today no I can attend.

I want you to tell your classmates that I can't attend.

(14) I: ITh.

Yeah.

Yeah.

(15) A: 'Indī zarf țārì wa-indanā iğtimā' fì l-qism fa-abīk tubllig zumalāìk annahu tamma tảağì al-muhāọdara.

I have circumstance urgent and we have meeting in the department so I want you tell your classmates that been postponed the lecture.

I have an urgent circumstance and we have a meeting in the department, so I want you to tell your classmates that the lecture has been postponed.

(16) I: İh ya'nīal-yawm mä fìh muhạdara?

Yeah it means today no there lecture?

Yeah, it means there is no lecture?

Excerpt 3 demonstrates an absence of pre-pres in the Australian English data. After opening and apology exchanges take place in lines 1-4, the Australian English native speaker (Neil) issues a couple of pre-expansions, lines 5 and 7. Then, he launches his base first pair part (request) in lines 9-11. Conversely, excerpt 4 shows frequent use of pre-pres in Saudi Arabic. After the production of long opening and greeting exchanges, lines 1-10, the Saudi Arabic native speaker (Ahmad) produces a pre-pre in line 11 (mumkin mink hidma?: "is it possible to do me a favour?") which serves to establish a pre-condition for the projected request. In turn, the interlocutor issues a go-ahead response in line 12 (tafaddal: "Sure"), providing the Saudi Arabic native speaker with the green light to proceed to the projected action. Indeed, he launches his base first pair part in line 13 (abīk tuballig zumaläik annī al-yawm mā aqdar ahdur: "I want you to tell your classmates that I can't attend"). Nonetheless, the interlocutor does not treat the Saudi Arabic native speaker's utterance in line 13 as a request; he instead produces a go-ahead response, line 14, assuming that it serves to be a pre-expansion. Before re-issuing his request, line 15, the Saudi Arabic native speaker launches a pre-expansion in line 15 which provides an account of the projected request.

According to Schegloff, pre-pres always appear before pre-expansion in talkin-interaction. ${ }^{34}$ However, pre-pres in this study occasionally appeared after

Schegloff, Sequence Organization in Interaction. 
pre-expansions. This trend was found in both the Australian English (2 out of 5 interactions) and Saudi Arabic (11 out of 31 interactions) data. It appears prepres not only occur before pre-expansions but rather after pre-expansions and before the base first pair part. Let us observe the following examples that illustrate the use of pre-pres after pre-expansions in both Australian English and Saudi Arabic.

Excerpt 5: Australian English native speaker: pre-pres after pre-expansions

(1) T: Hi (first name).

(2) I: Hi how are you?

(3) T: Good... Look, I haven't been able to do the shopping this week [

(4) I: [.hh.

(5) T: Because I've been busy with the assignments and staff as you can see.

(6) I: Yeah.

(7) T: => So I was wondering if you can do me a big favour?

(8) I: Sure.

Excerpt 6: Saudi Arabic native speaker: pre-pres after pre-expansions

(1) K: (First name) al-salām 'alaykum.

(First name) peace upon you.

(First name) peace be upon you (hello)

(2) I: Alaykum al-salām halā wa-Llah (first name).

Upon you peace welcome God (first name).

Peace be upon you (hello), very welcome (first name).

(3) K: Kayfa al-hāal?

How the condition?

How are you?

(4) I: Allahysallimik.

God grant you health.

May God grant you health.

(5) K: Wšlūnik?

How are you?

How are you?

(6) I: Bi-hayr Allah yuțawwil 'umrak.

Good God lengthen your life.

Good, may God grant you longevity.

(7) K: Mā indak ğāmía al-yawm?

No you have university today?

You aren't going to university today? 
(8) I: Lā wa-Llah mā 'indī šay' al-yawm fāḍ̄ wa-anā qā id atafarră̌ 'alā al-mubarā.

No God no I have anything today free and I being watching on the match.

Definitely not, I have nothing. I'm free today and I'm watching the match.

(9) K: Bi-l-lāhi?

By God.

Really?

(10) I: İwa-Llah.

Yes God.

Yes, indeed.

(11) K: Bi-tațla'makān?

Going place.

Are you going anywhere?

(12) I: Wa-Llahimāadrī.

Swear to God no I know.

Actually, I don't know.

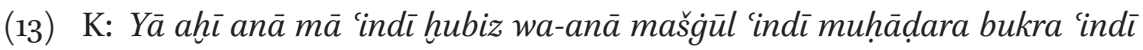
wāğibāt al-usbū' had̄ā wa-anā šà̇ḡāl 'alayhā.

Oh brother I no have bread and I busy I have lecture tomorrow I have homework week this and I working on them.

Brother, I don't have bread and I'm busy. I have a lecture tomorrow. I have homework this week and I'm working on it.

(14) I: Ih.

Yeah.

Yeah.

(15) $\mathrm{K}:=>$ Yāahì mumkin atlub mink talab basīt?

Oh brother possible I ask from you favour simple?

Brother, is it possible to ask you a small favour?

(16) I: Abšir āmir.

Yes sure.

Yes, sure.

In excerpt 5, the Australian English native speaker (Tony) issues his pre-expansions in lines 3 and 5 and then launches a pre-pre in line 7 ("so I was wondering if you can do me a big favour?"). Likewise, in excerpt 6, the Saudi Arabic native speaker (Khalid) produces a number of pre-expansions in line 13. He then issues a pre-pre in line 15 (yā ahī mumkin ațlub mink talab basīt?: "Brother, is it possible to ask you a small favour?"). Although these patterns contradict 
Schegloff's findings, ${ }^{35}$ it should be noted pre-pres were more commonly placed before pre-expansions than after.

Regarding the influence of power on the occurrence of pre-pres, Australian English native speakers rarely used pre-pres (housemate: 2 occasions; professor: 2 occasions; student: 1 occasions) perhaps indicating they were not significantly affected by power differentials. In contrast, power differentials did affect Saudi Arabic native speakers use of pre-pres. They employed pre-pres considerably more with their housemate ( 16 occasions) than with their professor (9 occasions) or a student (6 occasions).

\section{Insert-Expansion}

The results reveal that the frequency of post-first and pre-second insert-expansions was almost the same in the Australian English and Saudi Arabic data. It should be noted here that due to the design of this study, it was the role-play conductor who produced the first pair parts of the insert-expansions. Consider the following excerpts which exemplify the occurrence of post-first and presecond insert-expansions in both Australian English and Saudi Arabic.

Excerpt 7: Australian English native speaker: post-first insert-expansion

(1) P: Now look I've got uhm right now I know our class is coming up very $\operatorname{soon}[$

(2) I: [Yeah.

(3) P: But I've sort of a meeting with a visiting academic and we've got... a professorial board meeting.

(4) I: I see.

(5) P: And uhm it's just a short notice and since I've just seen you now, I was wondering if you could be so kind as to tell... Inform our classmates that there is no class so this might involve an extra ten minutes of your time waiting[

(6) I: [.hhh.

(7) P: At the classroom just telling them... there is no you know no class today. I was wondering if you could please do that.

(8) I: $=>$ So it means there is no class today?

(9) P: No class today and we will continue tomorrow.

(10) I: All right, I'll tell them. 
Excerpt 8: Australian English native speaker: pre-second insert-expansion

(1) S: We're running out of bread and I really haven't got time. I was wondering if it was... It would be all right... If you went and grabbed some bread from the supermarket[

(2) I: [Yeah.

(3) S: When you're ready?

(4) I: => So you want it right now or it's all right to bring it later?

(5) S: Half an hour is all right.

(6) I: All right I will.

Excerpt 9: Saudi Arabic native speaker: post-first insert-expansion

(1) Y: Abīk tuballig̉ zumalāik annī al-yawm mā aqdar aḥụur.

I want you tell your classmates I today no I can attend.

I want you to tell your classmates that I can't attend.

(2) I: İh.

Yeah.

Yeah.

(3) Y: 'Ind̄̄ zarf țāri' wa- indanā iğtimā' fı al-qism fa-abìk tuballig̉ zumalā’ik annahu tamma tảağīl al-muhạậra.

I have circumstance urgent and we have meeting in the department so I want you tell your classmates that been postponed the lecture.

I have an urgent circumstance and we have a meeting in the department so I want you to tell your classmates that the lecture has been postponed.

(4) I: => İh yainìal-yawm mā fìh muhādara?

Yeah it means today no there lecture?

Yeah, it means there is no lecture?

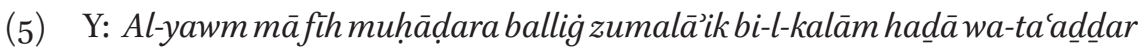
lìminhum.

Today no there lecture tell your classmates speech this and apologize for me from them.

Today there's no lecture. Tell your classmates about this and apologize for them on my behalf.

(6) I: Halāṣ abšir.

Ok I will.

Ok, I will.

Excerpt 10: Saudi Arabic native speaker: pre-second insert-expansion

(1) A: Idāa mā 'alayk kalāfa waddì bi-hubiz.

If no on you burden I want bread.

If it doesn't bother you, I want bread. 
(2) I: => Tibih alhin aw ba'dayn?

You want it now or later?

You want it now or later?

(3) A: Wa-Llahyalayt alhịn li-annī aḥis rūḥi ğay'ān.

Swear to God wish now because I feel myself hungry.

Actually, I wish now because I feel hungry.

(4) I: Anā bi-șarāḥa atafarrağ 'alā al-mubarā lakin barūḥ 'ašān'ik.

I honestly watching on the match but I'll go for you.

Honestly, I'm watching the match but I'll go just for you.

Excerpt 7 shows post-first insert-expansions occurred in the Australian English data. The interlocutor produces a post-first insert-expansion, i.e. repair, in line 8 ("so it means there is no class today?") to clarify the class has been cancelled. The Australian English native speaker (Peter) issues the second pair part of this repair sequence, confirming the cancellation of the class. The use of post-first insert-expansions also appeared in Saudi Arabic data. Excerpt 9 shows that the interlocutor launches a post-first insert-expansion in line 4 (ìh ya'nī al-yawm mā fìh muhādara?: "Yeah, it means there is no lecture today?"). Regarding production of pre-second insert-expansions, excerpts 8 and 10 illustrate that they occurred in both the Australian English and Saudi Arabic data. The interlocutor issues a pre-second insert-expansion with the Australian English native speaker (Sammons) in excerpt 8, line 4 ("So you want it right now or it's all right to bring it later?") and with the Saudi Arabic native speaker (Abdullah) in excerpt 10, line 2, (tibihh alhin aw ba'dayn?: "You want it now or later?"). The purpose of these pre-second insert-expansions is to obtain all necessary information before the production of the base second pair part, i.e. the response to the participant's request. This data suggests that insert-expansions were produced by Australian English and Saudi Arabic speakers.

When considering the influence of power on the production of post-first and pre-second insert-expansions across groups, it was found that power did affect the production of these two kinds of insert-expansions in both groups. With the housemate, post-first insert-expansions were rarely produced in either group (Saudi Arabic: 4 occasions; Australian English: 2 occasions) whilst pre-second insert-expansions were frequently produced in both (Saudi Arabic: 16 occasions; Australian English: 12 occasions). With the professor, post-first insert-expansions did not appear in either group whereas pre-second insertexpansions occurred frequently in the Australian English group (10 occasions). Pre-second insert-expansions did not exist in the Saudi Arabic group. With the student, post-first insert-expansions were commonly employed in both groups (Saudi Arabic: 13 occasions; Australian English: 9 occasions) whilst pre-second insert-expansions were not used in either group. Thus, it can be concluded that 
power affected both groups in terms of the occurrence of insert-expansions, demonstrating similarity between the two groups.

\section{Post-Expansion}

It was found that non-minimal post-expansions did not occur in the data due to the fact that all participants' requests were granted; in other words, the interlocutor never produced dis-preferred responses which normally lead recipients to issue non-minimal post-expansions. ${ }^{36}$ On the other hand, minimal post-expansions were employed in this study. The use of minimal postexpansions varied across groups; they were consistently employed by Australian English native speakers whereas they were very rarely employed by Saudi Arabic native speakers. The following two examples illustrate the frequent occurrence of minimal post-expansions in Australian English data and their absence in Saudi Arabic data.

Excerpt 11: Australian English native speaker: minimal post-expansion

(1) H: I was wondering if you could perhaps... I can get a copy of the lecture notes.

(2) I: Yeah, sure. Luckily I have extra copies... So this copy is for you.

(3) $\mathrm{H}:=>$ Great. Thanks very much.

(4) I: You're welcome.

(5) H: I appreciate it.

(6) I: No worries.

Excerpt 12: Saudi Arabic native speaker: no minimal post-expansion

(1) T: Kunt $\dot{g} \bar{a} i b$ al-muhāọdara al-mādiya wa-'indanā ahtibār al-usbūc alqādim fa-mumkin āhud al-mulahhașāt mink?

I was absent lecture last and we have exam next week, so possible I take lecture notes from you?

I was absent last week and we have an exam next week, so is it possible to take the lecture notes?

(2) I: Na'am 'indīnusah zāiida tafaḍdal hadihi lak.

Yes I have copies extra you may take this for you.

Yes, I have extra copies. You may have this one for you.

(3) T: Šukran ǧazīlan yā duktūr.

Thanks very much oh professor.

Thanks very much, professor.

$36 \quad$ Ibid. 
(4) I: Al-'afü.

Welcome.

Welcome.

(5) T: Ma'a al-salāma.

Bye good.

Good bye.

(6) I: Ma'a al-salāma.

Bye good.

Good bye.

In the former episode, it is evident that after the interlocutor produced a preferred response to the Australian English native speaker's (Hugh) request in line 2, the Australian English native speaker issues a minimal post-expansion in line 3 ("Great"), an indication of his acceptance of interlocutor's response. In the latter episode, however, it can be seen that although the interlocutor produces a preferred response (i.e. acceptance of the request), line 2, the Saudi Arabic native speaker (Turki) does not issue a minimal post-expansion but rather he launches a first pair part of a thanking-sequence in line 3. These two excerpts show that minimal post-expansions commonly occurred in Australian English data whereas they almost never appeared in Saudi Arabic data, possibly demonstrating that they do not exist or are not preferred in Saudi Arabic.

Regarding the effect of power on the production of minimal post-expansions across groups, it is not surprising that Saudi Arabic native speakers' performance of minimal post-expansions was not influenced by power given they rarely used them (housemate: 1 occasion; professor: 0 occasion; student: 2 occasions). Similarly, power did not affect the use of minimal post-expansions made by Australian English native speakers. They used minimal post-expansions regardless of power status with the housemate (13 occasions), professor (12 occasions) and student (12 occasions).

\section{Accounts in Request-Sequences}

Accounts are utterances used for providing reasons and explanations for unexpected or problematic actions. ${ }^{37}$ In request sequences, a requester may employ an account to reduce the possibility of a requestee interpreting a request as

37 John Heritage, Garfinkel and Ethnomethodology, Cambridge, Polity Press, 1984; John Heritage, "Explanation as accounts: A conversation analytic perspective," in Analyzing Everyday Explanation: A Casebook of Methods, ed. Charles Antaki, London, Sage, 1988, p. 127-144. 
unexpected. ${ }^{38}$ Goffman refers to this as "remedial work." ${ }^{39}$ The aim is to encourage the requestee to accept the dispreferred action (i.e. request) and limit the potential for the requestee to perceive the request as offensive. Heritage points out that accounts are "threat- and conflict-avoidance" practices and serve to reflect social solidarity on the part of the requester. ${ }^{40}$ They minimize the risk of loss of face or fracture to the relationship between the requester and requestee.

The placement of accounts in request sequences has been found to vary across languages. For instance, Schegloff reported that they were normally used prior to requests in English with the aim of postponing the dispreferred action, ${ }^{41}$ whereas Taleghani-Nikazm found that they were launched after the projection of the request in German. ${ }^{42}$ This paper has discussed the occurrence of accounts prior to requests (pre-expansions) and will now examine the production of accounts after the use of requests.

The production of accounts in request sequences varied across groups. Australian English native speakers rarely issued accounts after the production of base first pair parts (requests) whilst Saudi Arabic native speakers frequently issued accounts after the production of requests. These findings are exemplified in the following two excerpts.

Excerpt 13: Australian English native speaker: absence of accounts in a request sequence

(1) T: Hi (first name).

(2) I: Hi (first name).

(3) T: I'm glad I bumped into you. Uhm I was supposed to be having a tutorial this afternoon but as it turns out there's a bit of clash in my timetable.

(4) I: Yeah.

(5) T: And uhm I won't be able to make it, so I'm just wondering whether you'd be able to pass it on to the other students that... The tutorial has been cancelled?

(6) I: All right, so there is no tutorial today?

38 Taleghani-Nikazm, Request Sequences.

39 Erving Goffman, Relations in Public: Microstudies of the Public Order, New York, Basic

Books, 1971, p. 109.

40 Heritage, Garfinkel and Ethnomethodology, p. 273.

41 Schegloff, Sequence Organization in Interaction.

42 Taleghani-Nikazm, Request Sequences. 
Excerpt 14: Saudi Arabic native speaker: accounts in a request sequence

(1) N: Halä (first name).

Hi (first name).

Hi (first name).

(2) I: Halā wa-Llah (first name).

Hi God (first name).

Hi (first name).

(3) N: Kayf ḥāluk?

How your condition?

How are you?

(4) I: Allahysallimak.

God make you well.

May God make you well (good).

(5) N: Tayyib inšảllah?

Ok God willing?

Hopefully good?

(6) I: Ubširk.

Yeah.

Yeah.

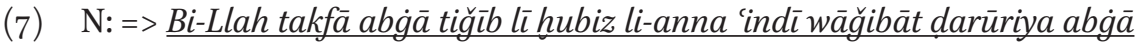
uhallishā wa-ğứān marra.

By God please I want bring for me bread because I have homework necessary I want finish them and hungry very.

Excuse me! Please I want you to bring me bread because I have necessary homework. I want to finish it and I'm very hungry.

(8) I: Marra?

Very?

Very?

(9) N: Abadan wa-lā 'alayk amr.

Absolutely and no upon you command.

Absolutely, I'm not commanding you.

(10) I: Tayyib.

Ok.

Ok.

Excerpt 13 shows that the Australian English native speaker (Tony) produces pre-expansions in lines 3 and 5 and then issues his request in line 5 . He does not provide accounts after the production of his request. In contrast, excerpt 14 reveals that the Saudi Arabic native speaker (Naif) launches his request in line 7 and immediately adds accounts to his request (li-anna 'indī wāğibät darūriya 


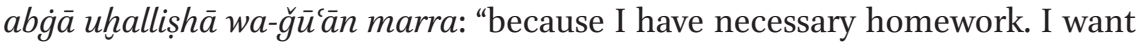
to finish it and I'm very hungry"). The Saudi Arabic native speaker's account is preceded by the use of li-anna (because), a connector, which indicates that what follows is the reason for the performed action, i.e. request. Thus, it becomes evident that the Saudi Arabic native speaker issued an account immediately after the request.

When examining the influence of power on the occurrence of accounts in request sequences, power had no effect on the occurrence of accounts in request sequences in the Australian English data (housemate: 2 occasions; professor: 3 occasions; student: 2 occasions) because they were rarely used. Likewise, Saudi Arabic native speakers' use of accounts in request sequences was not influenced by power (housemate: 7 occasions; professor: 9 occasions; student: 8 occasions).

\section{Discussion}

This paper examined aspects of sequence organization of requests in Australian English and Saudi Arabic and the effect of the social variable power. Overall, it was found that both languages shared some regularities of sequence organization whereas they differed in the occurrence of others. Power influenced the production of some regularities in both languages. Native speakers of both languages had a tendency to issue not only pre-expansions but multiple pre-expansions prior to the production of requests. These interactional moves were employed as a mitigation (i.e. providing accounts/explanations) and projection of the dispreferred action (request). This illustrates the similarity between Australian English and Saudi Arabic in relation to the production of pre-expansions. This finding supports previous research that found native speakers of English and German produced pre-expansions before issuing requests, and may indicate this interactional device is preferred across languages. ${ }^{43}$

However, not all accounts were utilized prior to the production of requests. The results showed they were sometimes used within the request sequence, in other words, after issuing requests. Interestingly, this interactional behavior was more common among Saudi Arabic native speakers than their Australian English counterparts. A possible explanation for this is that Saudi Arabic native speakers tended to use accounts to soften the illocutionary force of their requests, the majority of which were direct in contrast to those of Australian English native speakers which were more often indirect. This finding is consistent

43 Schegloff, Sequence Organization in Interaction; Taleghani-Nikazm, Request Sequences. 
with Roever and Al-Gahtani's study which reported use of accounts within request turns among Saudi Arabic native speakers. ${ }^{44}$ In addition, the placement of accounts within request sequences was found in other languages such as German. ${ }^{45}$ It then becomes apparent that accounts need not precede the production of requests but can also be used within request sequences and this interactional behavior varies across languages.

With regard to pre-pres, the results showed variation between groups. Namely, Saudi Arabic native speakers produced them considerably more than Australian English native speaker and this may suggest they are a common occurrence in Saudi Arabic. More importantly, the results showed pre-pres can be produced after pre-expansions. This is contrary to Schegloff's findings that pre-pres precede pre-expansions. ${ }^{46}$ Pre-pres following pre-expansions were more frequently employed in the Saudi Arabic data which may suggest Saudis prefer this format.

The production of insert-expansions (both types) occurred in both Saudi Arabic and Australian English and no marked differences were observed. This may indicate a similarity between the languages in this regard but it should be noted that, due to the design of this study, insert-expansions were issued by the interlocutor who played all role-play scenarios with the participants in both groups. As a result, the symmetry of insert-expansions in both languages could be attributed to the effect of the interlocutor.

In relation to post-expansions, non-minimal post-expansions did not appear in the data since participants' requests were instantly granted. On the other hand, minimal post-expansions occurred at varied rates across groups. Australian English native speakers tended to issue them very frequently while they were rarely employed by Saudi Arabic native speakers. This suggests possible cross-cultural differences regarding the use of minimal post-expansions.

The findings also illustrate the impact of power on the production of insertexpansions in Australian English and pre-pres and insert-expansions in Saudi Arabic. Other aspects of sequence organization were not affected by power. This may indicate that power influences how request sequences are organized and that the magnitude of its influence differs across languages. This finding supports traditional Interlanguage Pragmatics studies that have reported power impacts the production of requests. ${ }^{47}$

44 Roever and Al-Gahtani, "Multiple requests in Arabic as a second language."

45 Taleghani-Nikazm, Request Sequences.

46 Schegloff, Sequence Organization in Interaction.

47 Machiko Achiba, Learning to Request in a Second Language: Child Interlanguage Pragmatics, Clevedon-Buffalo, Multilingual Matters ("Second language acquisition", 2), 2003; 
In summary, this paper shows that using Conversation Analysis as an analytical tool is very useful for examining speech acts. It enables researchers to investigate new issues in Interlanguage Pragmatics that the traditional analytical approach (i.e. the Cross-Cultural Speech Act Realization Project coding scheme) failed to explore, for example, insert-expansions, post-expansions, multiple requests and the use of accounts in a request turn. In addition, using Conversation Analysis for Interlanguage Pragmatics research allows researchers to examine how certain utterances are accomplished in talk-in-interaction and how various languages use interactional devices which would not be possible under the traditional analytical approach. ${ }^{48}$

\section{Conclusion}

This paper investigated aspects of sequence organization of requests in Australian English and Saudi Arabic, and the effect of the social variable power. Overall, it was found they shared some regularities of sequence organization while differing in others. Power influenced the production of some regularities in both languages. As this study is the first of its kind and used role-play data, further research using natural data is needed to generalize its findings.

Tim Hassall, "Requests by Australian learners of Indonesian," Journal of Pragmatics, 35/12 (2003), p. 1903-1928.

48 Al-Gahtani and Roever, "Proficiency and sequential organization of L2 requests." 